\title{
Scott syndrome
}

\author{
INSERM
}

\section{Source}

INSERM. (1999). Orphanet: an online rare disease and orphan drug data base. Scott syndrome. ORPHA:806

Scott syndrome is an extremely rare congenital hemorrhagic disorder characterized by hemorrhagic episodes due to impaired platelet coagulant activity. 